
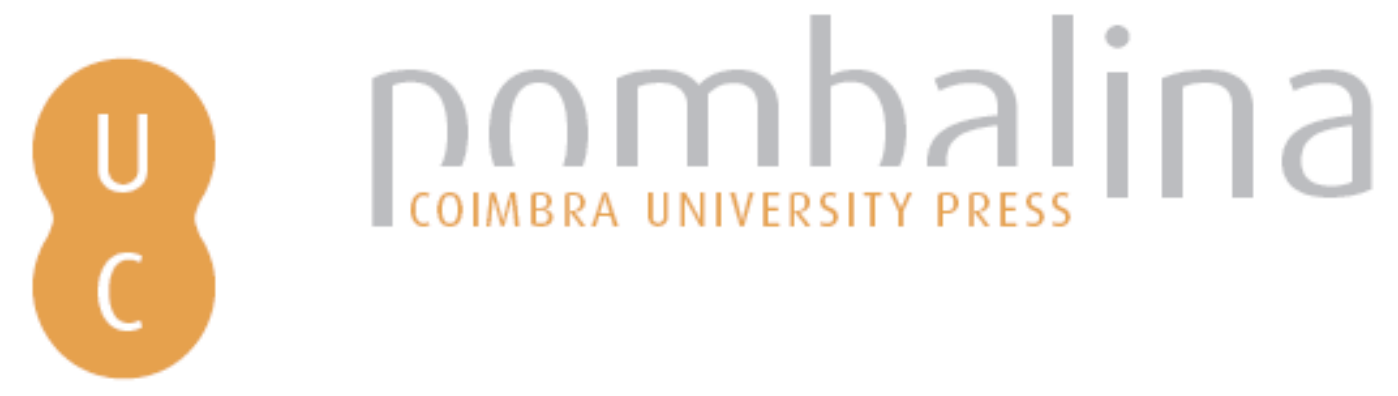

\title{
Controvérsias na identidade cristã segundo Eusébio de Cesareia, em História Eclesiástica
}

\author{
Autor(es): $\quad$ Medeiros, Edalaura Berny; Cerqueira, Fábio Vergara \\ Publicado por: Imprensa da Universidade de Coimbra \\ URL \\ persistente: URI:http://hdl.handle.net/10316.2/34761 \\ DOI: $\quad$ DOI:http://dx.doi.org/10.14195/978-989-26-0626-2_11 \\ Accessed : $\quad$ 26-Apr-2023 04:43:22
}

A navegação consulta e descarregamento dos títulos inseridos nas Bibliotecas Digitais UC Digitalis, UC Pombalina e UC Impactum, pressupõem a aceitação plena e sem reservas dos Termos e Condições de Uso destas Bibliotecas Digitais, disponíveis em https://digitalis.uc.pt/pt-pt/termos.

Conforme exposto nos referidos Termos e Condições de Uso, o descarregamento de títulos de acesso restrito requer uma licença válida de autorização devendo o utilizador aceder ao(s) documento(s) a partir de um endereço de IP da instituição detentora da supramencionada licença.

Ao utilizador é apenas permitido o descarregamento para uso pessoal, pelo que o emprego do(s) título(s) descarregado(s) para outro fim, designadamente comercial, carece de autorização do respetivo autor ou editor da obra.

Na medida em que todas as obras da UC Digitalis se encontram protegidas pelo Código do Direito de Autor e Direitos Conexos e demais legislação aplicável, toda a cópia, parcial ou total, deste documento, nos casos em que é legalmente admitida, deverá conter ou fazer-se acompanhar por este aviso.

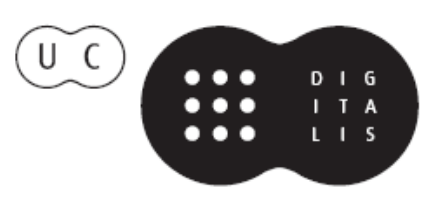




\title{
Saberes e poderes no Mundo Antigo
}

Estudos ibero-latino-americanos

\author{
Volume II - Dos poderes
}

Fábio Cerqueira, Ana Teresa Gonçalves, Edalaura Medeiros \& Delfim Leão (Orgs.)

IMPRENSA DA UNIVERSIDADE DE COIMBRA

UNIVERSIDADE FEDERAL DE PELOTAS

UNIVERSIDADE FEDERAL DE GOIÃS 


\title{
CONTROVÉRSIAS NA IDENTIDADE CRISTÃ SEGUNDO EUSÉBIO DE CESAREIA, EM HISTÓRIA ECLESIÁSTICA*
}

\author{
Edalaura Berny Medeiros \\ Fábio Vergara Cerqueira \\ Universidade Federal de Pelotas - Brasil
}

\begin{abstract}
Escrever a História, ou construir um discurso sobre o passado, é sempre um ir ao encontro das questões de uma época. A História se faz como uma resposta a perguntas e questões formuladas pelos homens em todos os tempos. Ela é sempre uma explicação sobre o mundo, reescrita ao longo das gerações que elaboram novas indagações e elaboram novos projetos para o presente e para o futuro, pelo que reinventam continuamente 0 passado. (PESAVENTO, 2005, p.59)
\end{abstract}

A influência do cristianismo na cultura ocidental é inegável. Em que pese a grande mudança verificável no comportamento do homem do século $\mathrm{XXI}$, em matéria de religiosidade, não há como ofuscar o fato de que somos profundamente marcados pelos conceitos e orientações fornecidos pela corrente judaico-cristã triunfante. Estamos nos referindo à facção judaica seguidora do nazareno Jesus, a qual nasceu no século I, cresceu no contexto do Império Romano e atingiu o seu ápice político em 380, sob Teodósio (347-395), com a derrota do último líder da oposição pagã, Nicômaco Flaviano (VÍLCHEZ, 2012, p.33).

O desenvolvimento do cristianismo foi tramado por constantes e sucessivos embates de cunho político-religioso ${ }^{1}$. Aqui é importante frisar que no Império Romano não havia uma distinção muito clara entre questões políticas e religiosas, pois tudo era do interesse do imperador, que cumulava com suas atribuições políticas o cargo de líder religioso (pontifex maximus). Portanto, quando nos referimos à união que se deu entre religião cristã e política romana,

\footnotetext{
* O presente artigo resulta da adaptação da Dissertação de Mestrado apresentada ao Programa de Pós-Graduação em História da Universidade Federal de Pelotas no ano de 2012, sob orientação do Prof. Dr. Fábio Vergara Cerqueira.

${ }^{* *}$ Mestre e licenciada em História e bacharel em Direito pela UFPel. E-mail: edalaura@hotmail.com. Agradeço imensamente a confiança e colabolação dos demais organizadores, em especial, meu orientador de mestrado, bem como o inestimável auxílio dos Professores Dr. a Monica Selvatici e Dr. Gilvan Ventura da Silva.

**** Professor Associado II do Departamento de História da UFPel. fabiovergara@uol.com.br
} 


\section{Controvérsias na identidade cristã segundo Eusébio de Cesareia}

estamos tratando da entrada definitiva das concepções cristãs na maneira de organizar e pensar as questões políticas ${ }^{2}$.

Voltando ao que se refere às ideias que triunfaram ao longo da história da igreja, percebemos que elas efetivamente ostentam o mérito de vitoriosas, pois, em boa parte, foram cunhadas através de imensos debates teóricos, filosóficos e religiosos. Em outras palavras, a análise da história da igreja nos permite visualizar um permanente esforço de reafirmação de poder e de hegemonia sobre a interpretação das sagradas escrituras ${ }^{3}$.

Um excelente exemplo de embate interno, que transparece o esforço de reafirmação de uma corrente teórica através discurso, está na Carta de Paulo aos Gálatas, redigida entre os anos de 54-55. Nela, o apóstolo se reporta enfurecido contra os pregadores que defendiam a prática da circuncisão e dos demais dispositivos da lei judaica, contrapondo a essa "justificação pelas obras" com o que chama de "justificação pela fé" (BROWN, 2004, p.621-9).

O tema dessa análise versa igualmente sobre controvérsias internas à igreja, todavia, não em seus primeiros anos, mas, no momento particular que exsurgiu do período conhecido como Anarquia Militar, denominado Império Romano Tardio. A Anarquia Militar foi um período de cerca de cinquenta anos (235 - 284) de crise generalizada provocada por problemas sucessórios, doenças e invasões bárbaras. Recebe essa denominação porque, em geral, o trono era ocupado por integrantes do exército. Segundo Ana Teresa Marques Gonçalves (2006, p.188), este período é caracterizado por problemas de diversas ordens, que envolviam crise política, militar, econômica, moral e religiosa. A partir do questionamento e reorganização do cenário social que emerge desse período de crise, verifica-se o nascimento de uma nova organização social, marcada por mudanças inicialmente políticas, com a formação da tetrarquia, por Diocleciano, e, posteriormente, religiosas, com a aproximação verificável entre o cristianismo e a administração imperial iniciada pelo tetrarca e posterior unificador do império, conhecido como o primeiro imperador cristão: Flávio Valério Constantino (272337).

Pretendemos, através das linhas que seguem, lançar um olhar crítico sobre o esforço de um cristão erudito do século IV para propor noções comportamentais aos demais cristãos, através da técnica de delimitação identitária formada pela oposição binária entre dois grupos existentes no Império Romano Tardio: cristãos e pagãos. Com isso, não se pretende ofuscar a importância das comunidades judaicas do período, o fato é que os atritos entre cristãos e pagãos são os que transparecem com mais intensidade na segunda parte da obra utilizada como fonte, onde o autor narra os eventos de sua contemporaneidade. Passemos, pois, à análise do documento suso. 
O objeto de nossa pesquisa é a obra pioneira da historiografia cristã, denominada História Eclesiástica ${ }^{4}$, escrita pelo bispo Eusébio de Cesareia (263339). História Eclesiástica é o livro que narra a história da Igreja, desde sua fundação, com Jesus Cristo, Filho de Deus, e concretização das profecias do Antigo Testamento, até o início do século IV, culminando com a unificação do poder imperial nas mãos de Constantino. Mais precisamente, Eusébio conclui a obra narrando os acontecimentos de 324, quando Constantino derrota o coimperador Licínio. Na introdução à obra, Roque Frangiotti (2000, p.23) assevera que, ao concluir sua narrativa no ano de 324, Eusébio evitou tratar dos episódios que envolveram o Concílio de Niceia, para não expor os conflitos internos à igreja, que motivaram o evento.

Os temas abordados por Eusébio são resumidos por T. Barnes (1981, p.129) da seguinte maneira: a sucessão dos bispos e imperadores; a história interna da igreja; escritores e mestres cristãos; o desenvolvimento da heresia; o destino dos judeus e a perseguição dos cristãos. H. A. Drake (2002, p.356-7) reúne os assuntos em cinco pontos: os bispos das mais famosas sés de cada geração; os trabalhos dos portadores de Palavra de Deus; o destino dos judeus; as heresias; as perseguições e os mártires. Para ele, a escolha dos temas é reveladora dos propósitos do autor: ao invés de tratar de milagres e relíquias, Eusébio se concentrou nos pontos essencialmente institucional e clerical, antecipando, em mais de um século, o princípio que passa a governar a história da igreja: "a igreja está nos bispos". Pela análise da obra, é possível constatar que os olhos de Eusébio estão voltados para os exemplos individuais que pontuaram a história do cristianismo.

Segundo Barnes (1981, p.128), nessa obra, Eusébio estabelece paradigmas identitários para tratar o cristianismo como uma identidade, a partir de novos elementos de coesão, diferente do estabelecimento de uma etnia, língua ou cultura comum. Para Eusébio, os cristãos se diferenciam por constituir uma "raça" moralmente superior. Dessa forma, a história dos cristãos não será a história de guerras e soldados, mas a história do povo que venceu através de uma guerra pacífica, eternizando os ensinamentos de verdade por sua bravura diante do martírio. Drake (2008, p.422), por sua vez, utiliza a expressão cunhada por Benedict Anderson - "comunidades imaginadas" - para definir o grupo cristão, que se autodefinia pela história e conjunto de crenças que partilhavam.

Para Drake (2002, p.356), Eusébio se preocupou com um assunto nunca antes analisado. Portanto, a originalidade da obra repousa em seu próprio objeto, que estimulou a elaboração de um novo método para a organização de registros dispersos e incompletos de povos que não se autodefiniam a partir das tradicionais categorias de identidade política, social ou cultural. Dessa forma, seu pioneirismo, para além da escolha do objeto e do desenvolvimento de um 


\section{Controvérsias na identidade cristã segundo Eusébio de Cesareia}

método próprio para organizá-lo e analisá-lo, encontra-se na criação de características de uma identidade para organizar fatos e eventos dentro de uma ótica particular, a teleológica. Desde o início de sua narrativa, Eusébio deixa evidenciada essa visão finalista dos acontecimentos:

Não quero outro exórdio a não ser o da realização da "economia" de nosso Salvador e Senhor Jesus, o Cristo de Deus. (Eus. HE 1.2)

E aponta, também, sua metodologia:

Colherei nesta espécie de prado espiritual as passagens mais apropriadas dos autores antigos, tentando reuni-las organicamente numa descrição histórica. (Eus. HE 1.4)

Antes da Grande Perseguição (303-313), a obra já estava publicada, mas apenas com os sete primeiros livros (BARNES, 1981, p.128). Os três últimos, Eusébio os escreveu porque sentiu a necessidade de registrar os acontecimentos que presenciou direta e indiretamente no contexto da perseguição de Diocleciano. Sobreviveu a ela porque se refugiou entre Fenícia, Egito e Arábia, onde coletou informações para a sua obra Mártires da Palestina, cuja versão enxuta compõe o livro VIII da HE. Por ocasião da promulgação do Edito de Tolerância, em 311, retornou à Cesareia e foi ordenado bispo em 313. (FRANGIOTTI, 2000, p. 10)

Eusébio utilizou exemplos de cristãos e pagãos para a narrativa dos eventos que presenciou. Essa escolha conferiu contradições à sua exposição, as quais foram sanadas pela lógica de seu discurso, cuja função "didática" faz com que a mensagem de fortalecimento da identidade cristã, pela ótica da formação de identidades por oposição binária, justifique impropriedades, contradições e até mesmo omissões.

Para Kathryn Woodward (2009), é a marcação da diferença que permite a construção de referenciais simbólicos, os quais, dentro de um sistema classificatório de percepção do mundo, constituem uma peça crucial para a construção da imagem do grupo. Tomaz Tadeu da Silva (2009, p.75), por sua vez, assevera que "as afirmações sobre diferença só fazem sentido se compreendidas em sua relação com as afirmações sobre identidade. (...) Assim como identidade depende da diferença, a diferença depende da identidade. Identidade e diferença são, pois, inseparáveis". Para Regina Maria da Cunha Bustamante (2006, p.111), o estudo da diferença depende da análise dos mecanismos utilizados para a formação da unidade social e cultural de um grupo, em um determinado momento histórico. Ou seja, importa na compreensão de que a identidade implica um conjunto de atribuições, próprios de uma época e de um grupo social, que, reconhecendo a pluralidade de sua composição e das inter-relações existentes, passam a se reconhecer e se diferenciar a partir desses contatos. 
Não almejamos elaborar um inventário dos elementos constitutivos da identidade cristã do século IV, mas apenas contribuir para os estudos voltados à análise das obras do nosso autor, lançando luzes sobre os pontos contraditórios de seu discurso. Entendemos que essa contradição não é voluntária e tampouco percebida por Eusébio, mas temos que as questões que serão colocadas foram tangenciais ao interesse do autor com a feitura da obra, qual seja, apresentar aos cristãos as origens remotas de sua religião, sua trajetória e o cumprimento da economia divina, com o fito de fortalecer o sentimento de pertença pelo enaltecimento dos feitos realizados pelos grandes líderes cristãos.

A nova identidade cristã, que transparece no discurso de Eusébio, em certo sentido é responsável pela proposta de uma nova identidade pagã, pois, como assevera Foucault, o discurso de verdade está diretamente relacionado com as instituições de poder.

É justamente a regra que permite que seja feita violência à violência e que uma outra dominação possa dobrar aqueles que dominam. Em si mesmas as regras são vazias, violentas, não finalizadas; elas são feitas para servir a isto ou àquilo; elas podem ser burladas ao sabor da vontade de uns ou de outros. O grande jogo da história será de quem se apoderar das regras, de quem tomar o lugar daqueles que se utilizam, de quem se disfarçar para pervertê-las, utilizá-las ao inverso e voltá-las contra aqueles que as tinham imposto; de quem, se introduzindo no aparelho complexo, o fizer funcionar de tal modo que os dominadores encontrar-se-ão dominados por suas próprias regras. As diferentes emergências que se podem demarcar não são figuras sucessivas de uma mesma significação; são efeitos de substituição, reposição e deslocamento, conquistas disfarçadas, inversões sistemáticas. (FOUCAULT, 1979, p.25-6)

Entendemos que, no discurso de Eusébio, é possível verificar a ocorrência da estigmatização ${ }^{5}$, pois o autor, em sua descrição de ícones dos grupos sociais rivais, transparece um esforço de delimitar elementos positivos inerentes aos cristãos, atentando para os aspectos negativos da alteridade, no caso, os pagãos. Tais contradições, por certo, encontram-se fortemente imbuídas pelo temor de uma reviravolta política, acompanhado da euforia decorrente da recente "virada" na estrutura de poder, que, em uma geração, colocou o cristianismo na condição de portador do discurso de verdade - compreendida nos termos propostos por Foucault:

(...) a verdade não existe fora do poder ou sem o poder. (...) A verdade é deste mundo; ela é produzida nele graças a múltiplas coerções e nele produz efeitos regulamentados de poder. Cada sociedade tem seu regime de verdade, sua "política geral" de verdade: isto é, os tipos de discurso que ela acolhe e faz funcionar como verdadeiros (...) o estatuto daqueles que 


\section{Controvérsias na identidade cristã segundo Eusébio de Cesareia}

têm o encargo de dizer o que funciona como verdadeiro. (FOUCAULT, 1979, p.12)

Focamos nos elementos que compõem a identidade cristã sugerida por Eusébio, que, em nossa opinião, vem expressa nos exemplos de personagens notáveis. Os cristãos são representados como figuras boas em todos os aspectos, enquanto os pagãos são introduzidos como indivíduos menores, inferiores, dados a toda sorte de mau comportamento. Partindo dessa premissa, queremos demonstrar que, no afã de elaborar uma demonstração "didática" da conduta esperada do cristão, assim como de apontar as atitudes reprováveis dos inimigos da fé, Eusébio não identificou qualquer contradição em sua exposição. Frise-se que essa ausência não compromete seu discurso, aliás, qualquer contradição fulminaria o próprio viés totalizante do mesmo. O importante é evidenciar a forma com que os fatos, visivelmente contraditórios, são perfeitamente alinhados à teoria proposta por Eusébio.

Em última análise, compreendemos que a questão de fundo da narrativa, o fato em si, utilizado para ilustrar certa visão de mundo, no caso, uma identidade, acaba em segundo plano, uma vez que o interesse do narrador não é exatamente o registro dos fatos, mas a valorização da identidade de seu grupo.

\section{História Eclesiástica: elementos contraditórios}

Entendemos que Eusébio contribuiu para a elaboração de uma nova identidade, através da delimitação de valores que, no seu entendimento, transpareciam na conduta dos cristãos notáveis, a saber: Constantino e os mártires da Grande Perseguição, dos quais destacamos Orígenes (182-254), fundador da Escola de Cesareia, onde Eusébio recebeu sua formação religiosa. Os mártires foram cristãos que enfrentaram tortura e morte pela fé que professavam, sem permitir que o terror abalasse suas convicções religiosas.

Nos termos propostos por Norbert Elias, o desviante comporta o outsider e o transgressor da norma de conduta interna a uma coletividade:

Afixar o rótulo de "valor humano inferior" a outro grupo é uma das armas usadas pelos grupos superiores nas disputas de poder, como meio de manter sua superioridade social. Nessa situação, o estigma social imposto pelo grupo mais poderoso ao menos poderoso costuma penetrar na autoimagem deste último e, com isso, enfraquecê-lo e desarmá-lo. (ELIAS \& SCOTSON, 2000, p. 24)

$\mathrm{Na} H E$, Eusébio apresenta três tipos de inimigos da fé: os judeus, os hereges e os perseguidores/pagãos. O termo pagão indicava pessoas que viviam no meio rural, nos pagos, alheios aos ensinamentos cristãos. Por esse motivo, a palavra passou a servir como designação indiscriminada para aquele que não era 
cristão, abarcando as diversas religiões politeístas, e criando, assim, um "rótulo" para sua alteridade, como prescreve Silva:

A exclusão se converte num fenômeno social mais complexo e turbulento, no entanto, quando ela não apenas dá margem à categorização dos grupos sociais, mas quando tal categorização é acompanhada de uma intensa carga valorativa informada, o mais das vezes, por concepções extraídas do senso comum, manipulando-se assim os princípios de classificação e divisão social com o propósito de submeter um grupo e/ou indivíduo, de situá-lo numa posição subalterna, o que acarreta, em contrapartida, o reforço dos códigos de conduta do grupo que opera esse tipo de distinção. Em suma, a exclusão exprime a sua face mais perversa quando ela é acompanhada por um processo de estigmatização, ou seja, pela atribuição de rótulos visando, por um lado, a minar a identidade daqueles que são excluídos e, por outro lado, a intensificar o carisma daqueles que possuem autoridade para excluir (...). (SILVA, 2009, p.23)

A primeira contradição na narrativa de Eusébio é localizada por Andréia Cristina Lopes Frazão da Silva: Eusébio omite o fato de as perseguições aos cristãos decorrerem de iniciativas do poder imperial, logo, do Estado. Para ela, Eusébio não reconhece qualquer incompatibilidade entre igreja e Império. Vejamos:

Para a $H E$, as perseguições aos cristãos sempre foram fomentadas pelos inimigos da fé cristã, incluindo as iniciativas de alguns imperadores maus. Mas os mártires cristãos suportaram os sofrimentos e mantiveram intacta a revelação de Cristo, conquistando o reconhecimento da população e dos próprios imperadores. Ou seja, os relatos das perseguições foram um dos argumentos apologéticos utilizados na $H E$ para demonstrar que a Igreja cristã do século IV, purificada pelo sofrimento, representava a religião verdadeira. (FRAZÃO, 2008, p.2)

Assim, Eusébio realiza uma individualização do oponente, apontando cada um dos imperadores favoráveis às perseguições como os verdadeiros inimigos da fé cristã. A concentração da reprovação na figura do imperador, e a sua desqualificação moral, afasta a atenção da possibilidade de que as perseguições representem a manifestação de uma sociedade enfurecida e contrária às práticas cristãs. Em outras palavras, ao manter o foco em um imperador específico, este responde exclusivamente pelos atos intentados contra os cristãos.

Dentro do argumento colocado por Frazão, é possível localizar ainda uma segunda contradição: a dupla condição do mártir, que sustenta, ao mesmo tempo, a qualidade de cristão fervoroso, exemplo de fé, mas também sofre as humilhações de uma morte tormentosa e, muitas vezes, sem herdeiros. A situação do mártir contradiz a teoria de Eusébio na qual associa a morte infausta 


\section{Controvérsias na identidade cristã segundo Eusébio de Cesareia}

e sem herdeiros dos imperadores inimigos do cristianismo ao castigo por uma conduta reprovável em vida. Vejamos:

Ao invés de seu predecessor Constâncio, ótimo e suavíssimo imperador, que exercera dignamente o poder, durante todo o reinado, e tendo se mostrado, aliás, muito acolhedor e beneficente para com todos (de fato, manteve-se alheio à luta contra nós, preservou de dano e vexações os súditos, adoradores de Deus, não destruiu as igrejas e nada absolutamente empreendeu contra nós), recebeu a recompensa de um fim de vida realmente feliz e três vezes abençoado e, ao morrer, foi o único a deixar feliz e gloriosamente o império a seu filho legítimo, sucessor no poder, em tudo prudente e piedoso. (Eus. HE 8, Ap.4)

Como é possível depreender pela análise da transcrição acima, Constantino teve morte tranquila e com herdeiros, graças à boa conduta em vida. Encontramos em Constantino uma terceira contradição, que reside na omissão de suas práticas reprováveis e na exacerbação dos atos idênticos praticados pelos imperadores inimigos da fé. Antes de tratar de Constantino, passemos à análise dos relatos das mortes dos demais imperadores.

O final trágico dos imperadores inimigos do cristianismo, a vitória e as qualidades cristãs de Constantino, são assuntos recorrentes nos livros VIII e IX. Estabelecendo um paralelo entre a conduta reprovável em vida em contraponto com a situação de morte, Eusébio relata o final dos imperadores pagãos, pois, para ele, "não convém passar sob silêncio qual o termo da vida de todos eles" (Eus. HE 8, Ap.1). São eles: Maximino, que "pereceu de morte vergonhosa", sob Licínio (Eus. HE 8.13.15); Maxêncio, que padece sob as tropas de Constantino, nas cercanias de Roma, recebendo um Salmo na narrativa de sua morte, "Ele cava e aprofunda um buraco, mas cai na cova que fez. Sua maldade se volta contra a cabeça, sobre o crânio the cai a própria injustiça" (SI.7.16-17 apud Eus. HE 9.9.6); Licínio, que governava o Oriente, dividindo o Império com Constantino, imperador do Ocidente, e que, segundo Eusébio, foi "atacado de demência", perdendo o poder para Constantino (Eus. HE 9.9.1); e, por fim, Galério, o "primeiro responsável da desastrosa perseguição e muito antes da entrada em ação dos outros imperadores" (Eus. HE 8, Ap.1), cuja fatal enfermidade mereceu uma descrição pormenorizada, digna de transcrição, tanto na $H E$ quanto na obra biográfica do imperador, também de autoria de Eusébio, denominada Vida de Constantino ${ }^{6}$ (340-341):

Com efeito, de repente brotou um abcesso nas partes mais escondidas do corpo; depois uma úlcera profunda com fístula, e esses males incuráveis corroeram-lhe as entranhas, onde formigava uma quantidade enorme de vermes; elas exalavam um cheiro pestilento. Toda a corpulência resultante da gula e que antes da moléstia comportava dobras de excessiva gordura, 
Edalaura Berny Medeiros e Fábio Vergara Cerqueira

pôs-se a apodrecer e oferecia aos circunstantes um espetáculo intolerável e assustador.

Dentre os médicos, uns não puderam de forma alguma suportar o estranho e intenso mau cheiro, e foram degolados; outros, impotentes para aliviar todo esse inchaço, para o qual não restava possibilidade de salvação, sem compaixão foram mortos. (Eus. HE 8.16.4-5)

O caso de Galério também merece de nossa parte uma atenção especial. Para Eusébio, as chagas suportadas pelo imperador constituíam um castigo de Deus, pelos males impostos aos cristãos. Dessa maneira, Galério teria promulgado o Edito de Tolerância, em 311, para se reconciliar com o Deus dos cristãos. Então, no apêndice do oitavo livro, Eusébio narra que o imperdador, após o Edito, "logo se viu livre de suas dores, mas por breve tempo, e morreu." (Eus. HE 8, Ap.1)

O interesse em relatar o final trágico dos perseguidores do cristianismo é verificável nos escritos de Eusébio, assim como de Lactâncio (240-320), que redigiu uma obra denominada $A$ morte dos perseguidores. Ambas as iniciativas associam o sofrimento da morte dos perseguidores a um castigo de Deus pela postura que assumiram, como inimigos do cristianismo (DRAKE, 2002, p.359). Mas, como já mencionado, os mártires também passaram por morte ignominiosa, o que, num primeiro momento, contradiz a teoria do castigo divino pessoal. Ou seja, os mártires, que, em Eusébio assumem a condição de exemplos de conduta cristã, são assim reconhecidos e enaltecidos justamente por padecerem de morte sofrida.

Eusébio foi testemunha ocular de alguns martírios, registrando-os com riqueza de detalhes em sua obra. Para que possamos apreciar o teor de sua narrativa, transcrevemos o seguinte excerto, no qual relata o martírio de cristãos na Tebaida:

Nós mesmos vimos, estando no próprio local, grande número de mártires sofrerem juntos, num só dia, uns a decapitação, outros o suplício do fogo, de tal forma que se o ferro mortífero ficava embotado e gasto era esmigalhado e os próprios carrascos, fatigados, alternavam-se uns aos outros.

Então, contemplamos o admirável ardor, o poder verdadeiramente divino, a coragem dos que acreditaram no Cristo de Deus. Pois, enquanto se pronunciava a sentença contra os primeiros, alguns acorriam de outro lado para o tribunal, diante do juiz. Declaravam-se cristãos, sem se inquietarem por causa dos tormentos nem das diversas espécies de suplícios aos quais se expunham; mas falavam com inteira liberdade, corajosamente, da religião do Deus do universo e recebiam alegres, risonhos, bem-humorados a sentença final de morte, cantando hinos e dando graças ao Deus do universo até o último suspiro. (Eus. HE 8.9.4-5) 


\section{Controvérsias na identidade cristã segundo Eusébio de Cesareia}

Na contramão da individualização do inimigo, portanto, há a generalização da Igreja, ou seja, os mártires, enquanto exemplos de fé, não podem ter sido merecedores de suas mortes trágicas. Dessa maneira, o mártir seria aquele que paga pelos erros de todos os cristãos. Para melhor explicitar essa questão, devemos analisar o teor do seguinte trecho, que consiste numa espécie de introdução à segunda parte da obra, quando Eusébio passa a narrar os acontecimentos de seu tempo:

Ultrapassa nossas forças expressar de modo adequado a grandeza e a
qualidade do respeito e da liberdade de que, antes da perseguição
contemporânea, usufruía a pregação da religião do deus do universo,
anunciada por Cristo a todos os homens, gregos e bárbaros, a fim de ser
vivida. (...)
Mas, a inteira liberdade degenerou em relaxamento e descuido, nós nos
invejávamos, injuriávamos mutuamente, e quando havia oportunidade,
pouco faltava para que nos combatêssemos com as armas, ou com as
lanças das palavras; os chefes em desavença com os chefes, o povo contra
o povo. A maldita hipocrisia e a dissimulação haviam atingido o mais alto
grau de malícia. Então, como habitualmente, o juízo de Deus, que
governava com suavidade e medida, era protelado (ainda se reuniam as
assembleias). Foi entre irmãos que pertenciam ao exército que começou a
perseguição. (Eus. HE 8.1.1.7)

Ou seja, foi o mau comportamento dos cristãos, em tempos de paz, que provocou a ira de Deus, ocasionando as perseguições de sua contemporaneidade. Nessa ótica, Eusébio teria evitado relacionar a morte trágica dos mártires com eventual conduta pregressa reprovável, mas estende a responsabilidade a toda a coletividade dos cristãos.

Para Eusébio, os mártires são os cristãos mais perfeitos e completos, pois, com sua coragem, não se deixavam dobrar, mesmo sob graves torturas. Não negavam a fé, garantindo, portanto, a salvação eterna e demonstrando, com seu sacrifício, o valor e a verdade do cristianismo. Desta forma, o autor descreve diversos martírios, ressaltando detalhes, muitas vezes macabros, com o objetivo, sobretudo, de demonstrar que todo aquele sofrimento não foi em vão; ao fim, a Igreja alcançara a vitória (FRAZÃO, 2008, p.15).

Dessa maneira, Eusébio evitou macular a imagem do mártir deitando suspeita sobre sua conduta pregressa. Além da morte tormentosa, a morte sem herdeiros também era negativa. Nesse ponto, também é possível verificar incoerência, bastando uma breve análise da trajetória do mártir mais admirado por Eusébio: Orígenes. Além de padecer sob martírio, ao que se sabe, Orígenes morreu sem herdeiros, pois realizou autocastração quando ainda era jovem, o que gerou muitas críticas na época (BARNES, 1982, p.84). 
Em contraposição à narrativa da vida dos imperadores inimigos do cristianismo, Eusébio se refere a Constantino como um grande homem e grande imperador.

Foi certamente desta forma que o rei soberano, Deus do universo e Salvador, contra tiranos muito ímpios, suscitou Constantino, (...) foi imperador, filho de imperador, piedoso, oriundo de pai piíssimo e sapientíssimo (...) (Eus. HE 9.9.1)

Drake afirma que Constantino não foi retratado como o habilidoso negociador, paciente construtor de consensos e ardente reformador judicial, senão através de breves referências. Pelo contrário, Constantino é retratado como um filho da Igreja, inteiramente voltado para erradicar a sujeira dos ímpios. A deliberada descrição do imperador demonstra que era do interesse de nosso autor promover certas ideias a respeito do cristianismo através da descrição de seus principais, no caso, o imperador. Ocorre que sua narrativa, como qualquer outra, não é despida de interesse e, para Drake, Eusébio escolhe o que lhe parece mais importante para dar significado à trajetória do imperador, de acordo com seu próprio esquema conceitual. (2002, p.357-358)

Segundo Drake (2002, p.359), os cristãos enquadravam todos os acontecimentos em seu modo explicativo, o que implicava em um viés óbvio em suas narrativas. Afirma que Eusébio não está fora dessa situação e aponta outras contradições, sintetizando-as nos seguintes tópicos: o primeiro dos tetrarcas a morrer não foi nenhum dos inimigos da fé, mas Constâncio I, o pai de Constantino, que teve pouca participação nas perseguições aos cristãos; afirma que aqueles que ergueram as mãos contra Deus morreram sem herdeiros, enquanto Constâncio I e Constantino os tiveram em abundância, mas omite que Constantino mandou matar seu primogênito Crispo (e sua esposa Fausta), e, o que Eusébio já não presenciou foi que, apesar de ter deixado três filhos, aquele que subiu ao trono alguns anos depois foi um de seus dois sobrinhos, Juliano, que era contrário ao cristianismo; e, por fim, outra contradição que a história vindoura revelará, a queda do Império Romano nas mãos dos inimigos, destino evitado pelos pagãos por um milênio. Para Drake (2002, p.359-360), os cristãos ignoraram tais reveses em suas narrativas, mantendo o foco no que lhes era interessante para justificar seu ponto de vista. Mas afirma que não é por isso que Eusébio deixou de estar comprometido com a narrativa da verdade, pois sua manifestação resulta do esforço para elucidar o sentido implícito da história.

As arbitrárias omissões de Eusébio sobre Constantino foram entendidas por Burckhardt, no século XIX, como desonestidade (DRAKE, 2002, p.357). Martín Garruchaga (2010, p.63), autor da introdução à obra Vida de Constantino, de Eusébio de Cesareia, por sua vez, afirma que o bispo não possuía grande discernimento acerca das forças que compunham seu cenário social, o que o 


\section{Controvérsias na identidade cristã segundo Eusébio de Cesareia}

impossibilitava de entender a conjuntura de sua época. Ao contrário, concentrouse na contraposição de Constantino aos demais soberanos, adotando a lógica do tirano castigado por Deus. Por fim, critica o estilo de escrita do autor ${ }^{7}$.

Drake (2002, p.351-2) resume o esforço cristão afirmando que seus eruditos nada tinham de obtusos, mas, ao contrário, voluntariamente assumiram o registro dos acontecimentos, atentando para as questões que efetivamente auxiliassem a organizar seu complicado passado ${ }^{8}$. E alerta ainda que, obviamente, Eusébio não escreveu a $H E$ de forma desinteressada, pois apesar de seu apreço pelo uso dos documentos, era seletivo, partidário e tinha a preocupação de interpretar os eventos a partir de seu próprio aparato conceitual. Além disso, informa que a inovação de Eusébio em relação à historiografia clássica grecoromana, que se restringia à narrativa dos eventos do ponto de vista do vício ou da virtude do indivíduo, é que, agora, o vício e a virtude são atribuídos a todo o grupo, enquanto a explicação dada aos acontecimentos, que outrora recaía sobre o destino ou fortuna, agora repousava no pecado e retribuição, pois o vício, para além de um atributo pessoal, traz, agora, a ira de Deus. Tratando o pecado e retribuição como a força motriz da história, Eusébio apresenta uma nova explicação para os acontecimentos, dentro do paradigma da Providência divina (DRAKE, 2002, p.357-362).

Assim, é imensa a contribuição da $H E$ para a sua contemporaneidade, solucionando conflitos internos e externos ao cristianismo com uma explicação global dos acontecimentos históricos. Não podemos olvidar sua importância também para o historiador atual, que, através da análise dessa rica e atraente obra, tem a oportunidade de se colocar mais próximo dos embates que marcaram o complexo contexto da Antiguidade Tardia.

Entendemos que o esforço de enaltecimento do cristianismo estava acima do trabalho de relatar os fatos que davam aporte aos exemplos. Assim sendo, dentro do discurso identitário de Eusébio, as contradições apontadas (ausência de incompatibilidade entre Igreja e Estado - com a individualização do inimigo na figura do imperador e a coletivização dos cristãos, cujos pecados foram pagos pelo sofrimento dos mártires; o mártir como exemplo de conduta e enfrentando, ao mesmo tempo, morte trágica e sem herdeiros, que contrapõe a justificativa do castigo de Deus, com a morte nefasta e sem herdeiros dos imperadores inimigos do cristianismo; deliberadas omissões de Constantino em contraponto com a descrição pormenoroizada das atitudes reprováveis dos imperadores pagãos) são suprimidas em nome de explicação que confere coerência aos acontecimentos, uma explicação que propõe o enaltecimento das figuras cristãs e a depreciação de seus inimigos. 


\section{Considerações finais: a incoerência obscurecida em nome do discurso totalizante}

A transição do paganismo para o cristianismo, no seio do Império Romano, ocorreu de forma gradual, mesmo sob o reinado de um imperador cristão. 0 primeiro, em movimento de declínio, ante o desmantelamento das estruturas políticas e sociais que lhe davam suporte, e o segundo, em franco crescimento, após o término das perseguições e graças às contribuições de Constantino, que se valeu de sua condição de liderança política para suprimir as dissenções internas e fornecer estímulo financeiro e político aos cristãos e seus bispos.

O cristianismo dividia o cenário religioso com o judaísmo e com o conjunto de religiões oriundas das tradições greco-romanas e orientais, denominado paganismo. $\mathrm{O}$ embate entre seus adeptos gerou uma série de conflitos teológicos, morais e políticos, que fomentaram uma extensa produção de textos com ofensas recíprocas, por parte dos líderes religiosos e filósofos.

Graças à atitude dos cristãos frente às perseguições, representada pelos mártires, que enfrentavam corajosamente os suplícios, alguns se entregando voluntariamente às autoridades para receber a pena capital, o cristianismo recebeu grande notoriedade. 0 trabalho dos teóricos cristãos contribuiu para o seu crescimento. Diante das adversidades, o movimento se tornava cada vez mais coeso. Porém, como nosso próprio autor reconhece (Eus. HE 8.8), em períodos de paz, os cristãos voltavam sua atenção para as questões teológicas e comportamentais, promovendo contendas internas. As múltiplas interpretações das Escrituras provocaram desentendimentos entre as lideranças cristãs, os quais dificilmente seriam resolvidos sem a participação de uma grande força externa, a mão imperial.

Portanto, os elementos identitários presentes na $H E$ são utilizados por Eusébio com o evidente propósito de elaborar uma narrativa que responda à necessidade de justificar o cristianismo, um novo elemento de destaque na conjuntura social do século IV. Para a elaboração da primeira parte de sua obra histórica, a qual foi escrita durante a Pequena Paz da Igreja (260 a 303), Eusébio utilizou escritos antigos que remetem à história dos hebreus e dos cristãos. Já, no que concerne aos acontecimentos de sua contemporaneidade, além de carecer de registros reconhecidos e respeitados por sua condição de histórico, como é o caso do Antigo Testamento, a história do cristianismo sofre uma crise, diante das perseguições imperiais. Dessa forma, para empregar coerência à sua retórica, Eusébio elege o sofrimento dos mártires como exemplo de conduta, enaltecendo o sofrimento dos cristãos condenados à morte, e apresentando o imperador cristão como enviado de Deus para a realização da vitória do cristianismo sobre as demais religiões. 


\section{Controvérsias na identidade cristã segundo Eusébio de Cesareia}

Detivemo-nos na comparação traçada entre Constantino e alguns imperadores anticristãos que participaram da Tetrarquia (Maximino, Maxêncio, Licínio e Galério). O enaltecimento da figura de Constantino, através da supressão do registro de suas atitudes reprováveis e pelo enaltecimento de suas qualidades, deixa transparecer um esforço de valorização daquele personagem, que entendemos como um ícone do cristianismo. Assim, pela dificuldade para delimitar os elementos formadores da identidade cristã, nosso autor recorre à narrativa da história desse grupo, que não possuía nenhum elemento aparente de vinculação (étnica, cultural, familiar, ou de outra ordem), senão a crença no Messias. Portanto, a história é utilizada como uma ferramenta para o estreitamento dos laços identitários dessa coletividade, e, por sua vez, os exemplos de personagens notáveis desempenham o papel de ilustrar o comportamento almejado do verdadeiro cristão. O enaltecimento dos feitos realizados pelos personagens selecionados conferia valor à identidade defendida pelo nosso autor. Da mesma forma, a depreciação da alteridade, no caso, o paganismo, aumentava o apreço pela identidade defendida.

Para que sua retórica não se desvie de sua lógica interna, Eusébio empregou valores diferentes na narrativa dos cristãos (o nós) e dos pagãos (o eles). Através da presente análise, foi possível verificar que o sofrimento da morte do cristão é valoroso, enquanto o sofrimento da morte do pagão é o resultado de sua conduta pregressa. Assim, fica em segundo plano a morte com herdeiros, considerada uma dádiva de Deus, quando o alvo da descrição é um mártir cristão, como Orígenes. Vemos, ainda, que, no intento de preservar imaculada a imagem de Constantino para a posteridade, Eusébio, deliberadamente, omite suas atitudes reprováveis. Enfim, para a narrativa dos fatos de sua contemporaneidade, Eusébio lançou mão de exemplos de cristãos em contraposição a alguns exemplos de pagãos, organizando os fatos e valores de forma a se enquadrarem na lógica de seu discurso. Sob esse prisma, é possível localizar um viés pedagógico na narrativa de nosso autor.

Portanto, a narrativa de Eusébio é comprometida com sua realidade, nela o autor demonstra amplo entendimento sobre as questões político-religiosas de seu tempo. Acreditamos que Eusébio possuía grande discernimento de seu contexto histórico, sobretudo da importância da intervenção imperial para a unificação da Igreja, sem a qual o seu crescimento restaria comprometido. O que pode ser considerado como falta de compreensão dos fatos, em verdade consiste na maneira como o autor visualiza e expõe as questões de seu tempo. Em suma, compreendemos que Eusébio, ao escrever a obra objeto de nossa pesquisa, desempenhou aquilo que se propôs, pois pretendia narrar a história da Igreja, destacando a participação de certos personagens (Eus. HE 1.1-2). 
Não ousamos questionar a verdade de suas alegações. Não há dúvida de que se trata de uma obra historiográfica. Eusébio elaborou sua narrativa acreditando na produção de um texto fiel aos acontecimentos selecionados, ou seja, estava comprometido com o registro da verdade, o que é demonstrado pela seleção e transcrição de suas fontes. Quando tratamos de "verdade", nos referimos ao modelo proposto por Foucault (1979, p.12) - "regimes de verdade", ou seja, um discurso que, para aquela coletividade funcionava como verdadeiro.

Tampouco pensamos que haveria de ser diferente. A lógica interna de um discurso totalizante não fornece elementos para a supressão de contradições, haja vista que sequer considera a existência delas. Sustentamos que as controvérsias não são suprimidas pela explicação, pois o discurso, em si, não possui esse condão. Mas, é em nome desse discurso, que Eusébio propõe uma lógica para os acontecimentos históricos, no caso a "economia" de Deus (Eus. HE 1.1-2). Em última análise, se o autor considerar que existam tais incoerências, o próprio esforço de explicação da realidade se esvazia.

Eusébio marcou a história como um verdadeiro porta-voz de seu tempo. Basta compreendermos suas intenções e o modelo de sua narrativa para que possamos usufruir dos elementos que nos permite vislumbrar acerca do contexto em que viveu e produziu. Sendo assim, é indispensável destacar que a presente análise, de nenhuma forma, pretende macular a genialidade de nosso autor. Apenas nos propusemos retornar ao registro de sua contemporaneidade para observar sua compreensão acerca de algumas questões de relevo, estendendo aos estudiosos da antiguidade um novo convite para o estudo do período, através da obra de Eusébio de Cesareia, tão extensa quanto fascinante.

Fontes primárias:

EUSÉBIO DE CESAREIA, História Eclesiástica. Introdução e notas complementares de Roque Frangiotti. São Paulo: Paulus, 2000.

EUSEBIO DE CESAREA, Vida de Constantino. Introducción, traducción y notas de Martín Garruchaga. Madrid: Gredos, 2010.

\section{Referências bibliográficas:}

BARNES, T. Constantine and Eusebius. Cambridge: Harvard University Press, 1981.

BROWN, R. Introdução ao Novo Testamento. São Paulo, SP: Paulinas, 2004.

BUSTAMANTE, M.R. da C. Práticas Culturais no Império Romano: Entre a Unidade e a Diversidade. In: SILVA, G.V. da \& MENDES, N.M. Repensando o Império Romano. Perspectiva Socioeconômica, Política e Cultural. Rio de Janeiro-Vitória: MAUADEDUFES, 2006, p.109-136.

DRAKE, H. A. Constantine and the bishops. London: The Johns Hopkins University Press, 2002.

DRAKE, H. A. The church, society and political power. In: CASIDAY, A. \& NORRIS, F. (orgs.) The Cambridge History of Christianity: Constantine to c. 600. Vol.2. New York: Cambridge University Press, 2008, p.403-428. 


\section{Controvérsias na identidade cristã segundo Eusébio de Cesareia}

ELIAS, N. \& SCOTSON, J.L. Os Estabelecidos e os Outsiders. Rio de Janeiro: Jorge Zahar, 2000.

FOUCAULT, M. Microfísica do Poder. Rio de Janeiro: Edições Graal, 1979.

FRANGIOTTI, R. Introdução e notas complementares. In: EUSÉBIO DE CESAREIA, História Eclesiástica. São Paulo: Paulus, 2000, p. 9-28.

FRAZÃO, A.C.L. Cristãos X Judeus: A intolerância religiosa da Igreja Triunfante. Revista Teológica, Rio de Janeiro, ano 14 (nova fase), n. 17, 1999, p.16-22.

FRAZÃO, A.C.L. Reflexões Sobre os Martírios, a Obra História Eclesiástica de Eusébio de Cesareia e a Hagiografia Cristã. In: Ciclo de Debates em História Antiga. Dialogando com Clio, 18, I 2008, Rio de Janeiro. Anais Eletrônicos do XVIII Ciclo de Debates em História Antiga. Rio de Janeiro: Lhia, 2008. (CD-ROM) p.1-26.

GARRUCHAGA, M. Introducción. In: EUSEBIO DE CESAREA, Vida de Constantino. Madrid: Gredos, 2010, p. 7-121.

GONÇALVES, A.T.M. Os Severos e a Anarquia Militar. In: SILVA, G.V. da \& MENDES, N.M. Repensando o Império Romano. Perspectiva Socioeconômica, Política e Cultural. Rio de Janeiro-Vitória: MAUAD-EDUFES, 2006, p. 175-191.

MEDEIROS, E.B. Constantino e os Cristãos: A Ascensão do Cristianismo como Religião Oficial do Império Romano e o Desenvolvimento da Intolerância. In: CERQUEIRA, F. \& SELVATICI, M. (orgs.). Religião e Poder, do Mundo Antigo ao Moderno: Ensaios Acadêmicos. Pelotas: LEPAARQ/UFPel, p.211-236, 2009.

MOMIGLIANO, A. As Raízes Clássicas da Historiografia Moderna. São Paulo: Edusc, 2004.

PESAVENTO, S.J. História \& História Cultural. Coleção História \& ... Reflexões. 2. ed. 1. reimp. Belo Horizonte: Autêntica, 2005.

ROSA, C.B da. A Religião na Urbs. In: SILVA, G.V. da \& MENDES, N.M., in: Repensando o Império Romano. Perspectiva Socioeconômica, Política e Cultural. Rio de JaneiroVitória: MAUAD-EDUFES, 2006, p.137-159.

SILVA, G.V. Vertentes da intolerância religiosa no Império Romano: o caso dos Judeus. In: CERQUEIRA, F.V.; POZZER, K.M.P.; NOBRE, C.K. (Eds). Fronteiras e Etnicidade no Mundo Antigo. Anais do V Congresso da Sociedade Brasileira de Estudos Clássicos 2003, Pelotas. Canoas: ULBRA, 2005. p.167-178.

SILVA, G.V. Desvio social, exclusão e estigmatização: notas para o estudo da "História dos marginais". Dimensões, UFES, vol. 23 , 2009, p.13-29.

SILVA, T.T. da. A produção social da identidade e da diferença. In: SILVA, T.T. da. et al. (org.) Identidade e Diferença: A Perspectiva dos Estudos Culturais. Petrópolis, RJ: Vozes, 2009, p.73-102.

VÍLCHEZ, F. P. A Tradição e a Sobrevivência das Fontes Gregas e Latinas. In: OLIVEIRA, J.C.M. \& SELVATICI, M. Textos e representações da antiguidade: transmissão e interpretação. Maringá: Eduem, 2012.

WOODWARD, K. Identidade e diferença: uma introdução teórica e conceitual. In: SILVA, T.T. da. et al. (org.) Identidade e Diferença: A Perspectiva dos Estudos Culturais. Petrópolis, RJ: Vozes, 2009, p.7-72. 


\section{Notas}

${ }^{1}$ Sobre o embate social entre correntes religiosas diversas no seio do Império Romano, sugerimos a leitura de BUSTAMANTE (2006) e ROSA (2006).

${ }^{2}$ Sobre a fusão entre o pensamento cristão e a hierarquia imperial romana, um trabalho bastante esclarecedor é SILVA (2005).

3 Em MEDEIROS (2009) buscamos evidenciar alguns aspectos do cristianismo institucionalizado que se distanciaram do ideário primitivo do grupo, sobretudo no que concerne ao esforço de manter o afastamento entre questões temporais e religiosas.

${ }^{4}$ A obra História Eclesiástica, à qual nos referiremos também como $H E$, é a mais conhecida e citada das obras de Eusébio (FRANGIOTTI, 2000, p.23). Foi escrita em duas partes, a primeira é composta pelos sete primeiros livros, que retratam a história do cristianismo, desde o nascimento de cristo até o ano de 303, e a segunda parte, composta pelos três últimos livros, foi registrada especialmente para narrar a atitude dos cristãos durante o período que ficou conhecido como "Pequena Paz da Igreja" (260-303), o descontentamento de Eusébio para com o relacionamento entre os cristãos e a vitória do cristianismo sobre o mundo, através de Constantino. Eusébio também narrou uma série de martírios impingidos durante a Grande Perseguição (303-313), que foi a última perseguição imperial sofrida pelos cristãos. Foi testemunha ocular de muitos martírios, e transcreve-os com riqueza de detalhes em sua obra.

${ }^{5}$ Para compreender essa questão, nos valemos do estudo realizado pelos pesquisadores Norbert Elias e John L. Scotson, que gerou a obra Os Estabelecidos e os Outsiders. A partir da análise sociológica aplicada a uma comunidade denominada Winston Parva, realizaram um estudo teórico acerca da rivalidade entre grupos que ocupam diferentes situações de poder, sendo que os habitantes mais antigos daquela comunidade consideravam-se superiores aos recém-chegados, utilizando como justificativa elementos subjetivos, quando, em verdade, se estava diante de uma relação de poder imposta por questões estruturais. Resumidamente, a delimitação dos grupos se firmava no discurso de enaltecimento do estabelecido em detrimento do outsider, ofuscando a relação material que dava aporte à rivalidade.

${ }^{6}$ El caso es que, no bien hubo dado <éste>, por primera vez, comienzo al acoso de las iglesias, y contaminada su alma con la sangre de los justos y piadosos, la represalia enviada por Dios lo alcanzó empezando por su propia carne y no se detuvo hasta llegar al alma. Pues un repentino absceso le surge en medio de las partes innombrables de su cuerpo; después, una llaga fistulosa en la parte baja y una incurable corrosión de todo ello hasta las más íntimas entrañas, de donde dícese que bullía gran cantidad de gusanos y brotaba un hedor de muerte, dado que toda la mole corpórea, por la abundante ingestión de alimentos, se había transformado en una inmensa masa grasienta, que cuando comenzó a pudrirse, ofrecía un espetáculo insufrible y horripilante a los que se acercaban. (Eus. VC. 2.57.1-3)

${ }^{7}$ El segundo desencanto se sufre cuando se espera un refinado gusto literario a un dominio en el campo de la composición. Su estilo es, en general, pomposo, obscuro y pretencioso, y la mezcla de metáforas es cuando menos chocante. (...) Su manera de escribir es un reflejo de su carácter, y como escribía, así era Eusebio. Más acumulativo que productivo, más pedestre que genial, más registral que especulativo. En el orden religioso, llama la atención 
en un hombre de la Iglesia, sin ninguna dispersión que lo desviara de ese solo centro, lo estereotipado de sus expresiones, sin una nota personal. (GARRUCHAGA, 2010, p. 63)

8 "increasingly took charge of the record, they quite naturally focused their attention on those parts that helped them understand and make sense of their own complicated past". (DRAKE, 2002, p.351-2) 